\title{
Pengaruh Implementasi SistemPengembangan Sumberdaya Manusia Terhadap Kinerja Karyawan (Studi Kasus Pada Biro Rektorat Universitas Jabal Ghafur)
}

\author{
Husaini Abdullah \\ Program Studi Manajemen Fakultas Ekonomi \\ Universitas Jabal Ghafur
}

\begin{abstract}
ABSTRAK
Penelitian ini bertujuan untuk Mengetahui "Manajemen, Judul: "Pengaruh Implementasi Sistem Pengembangan Sumberdaya Manusia Terhadap Kinerja Karyawan (Studi Kasus Pada Biro Rektorat Universitas Jabal Ghafur".Dimana variabel independen yaitu Pendidikan, Pelatihan dan Kinerja Karyawan (Y) sebagai variabel dependennya.Populasi dalam penelitian ini adalahsemua karyawan Biro Rektorat Universitas Jabal Ghafur sebanyak 55 Orang Karyawan.Sampel diambil menggunakan total sample yaitu seluruh populasi di jadikan sampel.Sampel penelitian ini sebanyak 55 Orang.Data yang dihimpun dalam penelitian ini terdiri dari data primer dan data sekunder, baik data kualitatif maupun data kuantitatifdan melalui kuesioner yang diisi oleh responden.Kemudian data yang diperoleh dianalisis dengan menggunakan analisis regresi berganda. Analisis ini meliputi Uji Normalitas, Uji Multikolinearitas, Uji HeterokedastisitasUji Asumsi Klasik, Uji Hipotesis melalui Uji F dan Uji t, serta analisis Koefisien Determinasi $\left(\mathrm{R}^{2}\right)$. Berdasarkan hasil penelitian, diperoleh persamaan regresi: $\mathrm{Y}=1,070$ $+0,362 \mathrm{X} 1+0,390 \mathrm{X} 2$. Hasil analisis diatas dapat disimpulkan bahwa berdasarkan uji t diketahui bahwa Variabel Pendidikan berpengaruh secara positif dan signifikan terhadap Kinerja Karyawan Biro Rektorat Universitas Jabal Ghafur. Hal ini terlihat dari nilai signifikan $(0,000)$ lebih kecil dari 0,05 dan nilai thitung 4,292 > ttabel 2,006, Variabel Pelatihan berpengaruh secara positif dan signifikan terhadap Kinerja Karyawan Biro Rektorat Universitas Jabal Ghafur. Hal ini terlihat dari nilai signifikan $(0,000)$ lebih kecil dari 0,05 dan nilai thitung 4,550 > ttabel 2,006. Berdasarkan perhitungan koefisien determinasi (R2), menunjukkan bahwa Angka Adjusted R2 atau determinan sebesar 0,681 berarti 68.1\% faktor-faktor kinerja karyawan dapat dijelaskan oleh Pendidikan (X1), Pelatihan (X2), sedangkan sisanya 31,9\% dapat dijelaskan oleh faktor-faktor lain yang tidak diteliti dalam penelitian ini.
\end{abstract}

Kata kunci: Implementasi Sistem, Pengembangan Sumber Daya Manusia, Kinerja Karyawan

\section{PENDAHULUAN}

\section{Latar Belakang}

Sumber daya manusia sering disebut sebagai human resource, tenaga atau kekuatan manusia (energi atau power).Sumber daya juga disebut sumber tenaga, kemampuan, kekuatan, keahlian yang dimiliki oleh manusia.Seiring dengan perkembangan teknologi dan perubahanperubahan dunia yang semakin hari semakin kompleks, menuntut seseorang untuk selalu merefresh kembali kemampuan yang dimilikinya sesuai dengan kapasitas perubahan tersebut. Pada dasarnya manusia memiliki potensi dasar dan kemampuan yang idealnya akan terus menerus berkembang apabila diasah secara kontinyu dan berkelanjutan. Membangun karir merupakan salah satu tugas perkembangan yang akan dilalui dalam kehidupan individu yang harus terus meningkatkan kemampuannya agar dapat membangun karir ataupun jabatan yang dimilikinya. Sebaliknya, suatu organisasi juga akan semakin maju dan berkembang apabila sumber daya yang dimiliki oleh karyawannya baik dan berkualitas.

Karyawan dalam suatu organisasi memiliki kemampuan yang beragam, dilihat dari sektorsektor ataupun divisi yang ditempatinya.Perkembangan dibidang teknologi dan ilmu pengetahuan membuat organisasi harus semakin peka dalam peningkatan kualitas sumber daya yang dimilikinya.Tak jarang pula sumber daya manusia atau karyawan yang menduduki jabatan tertentu dalam organisasi mempunyai kemampuan yang sesuai dengan persyaratan yang diperlukan. Oleh karena itu untuk menyikapi fenomena tersebut perlu adanya tindak lanjut dari organisasi sebagai upaya agar kemampuan yang dimiliki karyawannya tidak statis akan tetapi berkembang secara dinamis.

Salah satunya yaitu dengan adanya pelatihan dan pengembangan karyawan.Program tersebut sebagai upaya organisasi untuk menjaga 
stabilitas organisasi dalam menghadapi tantangan dan perubahan global yang terjadi, terutama di dunia organisasi atau industri sehingga dapat terus eksis berdiri dan terus berkarya.Pelatihan dan pengembangan dilakukan sebagai upaya meningkatkan keterampilan dan pengetahuan yang dimiliki karyawan.Terutama menghadapi kondisi-kondisi baru.Hal ini berkaitan dengan karir dan diharapkan sebagai upaya dalam mengatasi adanya kadaluwarsa sumber daya manusia pada organisasi tersebut.Sebagai wujud pemenuhan kebutuhan pada karyawan yaitu kebutuhan untuk mengembangkan diri (aktualisasi diri) yang nantinya terkait dengan pengembangan karir karyawan.

Biro Rektorat Universitas Jabal Ghafur adalah unsur pimpinan yang membantu Rektor dibidang administrasi akademik dan kemahasiswaan yang berada di bawah dan bertanggung jawab langsung kepada Rektor dan sehari-hari di bawah pembinaanya dilakukan oleh Wakil Rektor I Bidang Adm Akademik, Wakil Rektor II Bidang Adm dan Keuangan, Wakil Rektor III Bidang Kemahasiswaan, Dekan Fakultas Teknik, Dekan Fakultas Non Gelar Teknik DIII, Dekan Fakultas Keguruan Dan Ilmu Pendidikan, Dekan Fakultas Ilmu Administrasi, Dekan Fakultas Pertanian, Dekan Fakultas Hukum dan Dekan Fakultas Ekonomi.

Beberapa program pengembangan sumber daya manusia telah dilaksanakan oleh Unigha bagi karyawannya.Selain pelatihan-pelatihan, unigha memberikan kegiatan pembelajaran untuk meningkatkan kompetensi karyawan melalui pendidikan bergelar (S1, S2, dan S3) di dalam negeri dengan beasiswa dari universitas maupun biaya sendiri.

Program pengembangan SDM yang dilakukan selama ini bagi karyawan Unigha dirasa masih belum memberikan hasil yang maksimal bagi instansi. Bentuk sistem pengembangan sumber daya manusia selama ini terlihat melalui pengembangan kemampuan karyawan yang antara lain dilaksanakan melalui peningkatan kemampuan untuk meningkatkan kinerja karyawan. Melalui pendidikan formal diharapkan dapat memberikan kontribusi terbesar dalam sistem pengembangan sumber daya manusia melalui materi pegembangan, membuat perbandingan, mengekspresikan ide melalui tulisan, membuat keputusan dengan kendalakendala tertentu dan lain-lain.Termasuk sistem pengembangan manusia melalui pendidikan formal merupakan pengembangan sikap tepat waktu, sikap kerapian, dan lain-lain.Melalui pengembangan sumber daya manusia selama ini terlihat dari tidak meningkatnya pengetahuan beberapa karyawan setelah mereka mengikuti program pendidikan, pelatihan, dan pengembangan.Bahkan tidak banyak perubahan dan tidak tampak peningkatan kinerja sesuai dengan yang diharapkan dari suatu pelatihan dan pengembangan setelah mereka kembali ke unit masing-masing.Bahkan bagi sebagian pegawai menganggap bahwa pelatihan dan pengembangan hanyalah kegiatan yang membuang waktu dan menjadi beban tambahan dalam pekerjaan mereka.Hal ini timbul mungkin karena pelatihan dan pengembangan yang dilaksanakan belum sesuai dengan kebutuhan karyawan, pemilihan metode yang digunakan dalam pelatihan juga tidak sesuai, waktu dan tempat pelaksanaan yang tidak tepat atau faktor-faktor lain yang dapat menyebabkan gagalnya suatu pelatihan.

Berdasarkan uraian di atas, maka peneliti tertarik untuk melakukan penelitian berjudul "Pengaruh Implementasi Sistem Pengembangan Sumberdaya Manusia Terhadap Kinerja Karyawan (Studi Kasus Pada Biro Rektorat Universitas Jabal Ghafur".

\section{Rumusan Masalah}

Berdasarkan latar belakang permasalahan yang telah dikemukakan sebelumnya, maka rumusan masalah yang diajukan pada penelitian ini adalah :

1. Bagaimana pengaruh implementasi pengembangan sistem SDM terhadap kinerja karyawan Biro Rektorat Universitas Jabal Ghafur?

2. Faktor manakah yang paling berpengaruh terhadap kinerja karyawan Biro Rektorat Universitas Jabal Ghafur?

3. Prioritas apa dan bagaimana pengaruh implementasi pengembangan sistem SDM Terhadap kinerja karyawan Biro Rektorat Universitas Jabal Ghafur?

\section{Tujuan Penelitian}

Tujuan dari penelitian ini adalah :

1. Untuk mengetahui pengaruh implementasi pengembangan sistem SDM terhadap kinerja karyawan Biro Rektorat Universitas Jabal Ghafur

2. Untuk mengetahui variabel yang paling dominan berpengaruh terhadap kinerja karyawan Biro Rektorat Universitas Jabal Ghafur

Jurnal Sains Riset | Volume VIII Nomor I 
3. Untuk mengetahui prioritas implementasi pengembangan sistem SDM Terhadap kinerja karyawan Biro Rektorat Universitas Jabal Ghafur

\section{Manfaat Penelitian}

Adapun manfaat penelitian yang dilakukan ini adalah :

1. Penelitian ini diharapkan bisa menjadi sumbangan dalam perbaikan terhadap kebijakan yang akan diterapkan dalam peningkatan kinerja karyawan pada Biro Rektorat Universitas Jabal Ghafur.

2. Bagi Program Studi Manajemen Universitas Jabal Ghafur Sigli, penelitian ini dapat dijadikan sebagai sumber informasi perihal kinerja karyawan yang ditinjau dari pengaruh implementasi program pengembangan sistem sumber daya manusia.

3. Bagi peneliti selanjutnya, Sebagai referensi bagi peneliti selanjutnya yang berkenaan dengan kinerja karyawan yang ditinjau dari pengaruh implementasi program pengembangan sistem sumber daya manusia.

\section{TINJAUAN PUSTAKA Implementasi}

Secara etimologis pengertian implementasi menurut Webster yang dikutip oleh Tachjan (2006:23) adalah:

"Implementasi yang merupakan terjemahan dari kata "implementation", berasal dari kata kerjan "to implement". Kata "to implement" berasal dari bahasa Latin "implementum" dari asal kata "impere" dan "plere". Kata "implere" dimaksudkan "to fil up"; " to fil in", yang artinya mengisi penuh; melengkapi, sedangkan "plere" maksudnya "to fil", yaitu mengisi”. (Tachjan, 2006:23 ).

\section{Selanjutnya kata "to implement" dimaksudkan sebagai: \\ "(1) to carry into effect; to fulfill; accomplist.} (2) to provide with the means for carrying out into effect or fulfilling; to give practical effect to. (3) to provide or equip with implements". "Pertama, to implement dimaksudkan "membawa ke suatu hasil (akibat); melengkapi dan menyelesaikan".Kedua, to implement dimaksudkan "menyediakan sarana (alat) untuk melaksanakan sesuatu; memberikan hasil yang bersifat praktis terhadap sesuatu". Ketiga, to implement dimaksudkan menyediakan atau melengkapi dengan alat" (Tachjan, 2006:23).

Jadi secara etimologis implementasi itu dapat dimaksudkan sebagai suatu aktivitas yang bertalian dengan penyelesaian suatu pekerjaan dengan penggunaan sarana (alat) untuk melaksanakan sesuatu dan memperoleh hasil.Sesuatu hasil tersebut yang diperoleh umumnya menimbulkan dampak atau akibat diantaranya peraturan perundang-undangan, peraturan pemerintah, keputusan peradilan dam kebijakan.Pengertian implementasi lainnya bahwa implementasi adalah: Sebuah tahapan yang dilakukan setelah aturan hukum ditetapkan melalui proses politik. Kalimat tersebut seolaholah menunjukan bahwa implementasi lebih bermakna non politik, yaitu administratif. (Kusumanegara, 2010:97).

\section{Sumber Daya Manusia}

Nawawi (2005:40), menjelaskan tiga pengertian dari sumber daya manusia, yakni:

1. Sumber daya manusia adalah manusia yang bekerja di lingkungan suatu organisasi (sering disebut juga personil, tenaga kerja, pegawai atau karyawan).

2. Sumber daya manusia adalah potensi manusiawi sebagai penggerak organisasi dalam mewujudkan eksistensinya.

3. Sumber daya manusia adalah potensi dan merupakan aset dan berfungsi sebagai modal (non material/non finansial) di dalam organisasi, yang diwujudkan menjadi potensi nyata secara fisik dan non fisik dalam mewujudkan eksistensi organisasi.

Menurut Sutrisno (2010: 4) sumber daya manusia adalah pegawai yang siap, mampu dan siaga dalam mencapai tujuan tujuan organisasi. Sebagaimana dikemukakan bahwa dimensi pokok sisi sumber daya adalah kontribusinya terhadap organisasi, sedangkan dimensi pokok manusia adalah perlakuan kontribusi terhadapnya yang pada gilirannya akan menentukan kualitas dan kapabilitas hidupnya.

Menurut Mathis dan Jackson (2008:3) Sumber Daya Manusia adalah rancangan sistemsistem formal dalam sebuah organisasi untuk memastikan penggunaan bakat manusia secara efektif dan efisien guna mencapai tujuan organisasi.

Dengan demikian sumber daya manusia merupakan faktor vital dari keberlangsungan

Jurnal Sains Riset | Volume VIII Nomor I 
sebuah organisasi dan yang paling menentukan dalam mengukur keberhasilan pencapaian tujuan organisasi.Sumber daya manusia yang dimaksud adalah orang-orang yang siap pakai dan memiliki kemampuan dalam pencapaian tujuan organisasi tersebut.

\section{Pengertian Kinerja}

Pada umumnya, kinerja diberi batasan sebagai kesuksesan seseorang didalam melaksanakan suatu pekerjaan.Kinerjaadalah kuantitas, kualitas, dan waktu yang digunakan dalam menjalankan tugas (Sutrisno, 2010: 172).Kinerjamerupakan wujud hasil kerja yang dihasilkan oleh seseorang. (Robbins, 2006: 35).Kinerjadinyatakan sebagai catatan outcomes yang dihasilkan dari suatu aktifitas tertentu, selama kurun waktu tertentu (Bernandin, 2006: 123). Kinerjaadalah apa yang dilakukan atau tidak dilakukan oleh karyawan dan seberapa banyak mereka memberi kontribusi kepada organisasi. Perbaikan kinerja, baik untuk individu maupun kelompok, menjadi pusat perhatian dalam upaya meningkatkan kinerja organisasi. (Mathis dan Jackson, 2008: 139).

Dari beberapa teori di atas, maka dapat ditarik kesimpulan bahwa yang dimaksud dengan kinerja adalah hasil kerja yang dicapai oleh seorang karyawan dalam memberikan kontribusi bagi organisasi atau perusahaan tempat ia bekerja. Prestasi karyawan dari sebuah perusahaan dapat terlihat dari kinerja yang telah ditampilkan. Seperti, bagaimana karyawan tersebut menggunakan waktu, kesempatan serta sumber daya dalam menghasilkan suatu output atau hasil kerja. Suatu kinerja yang baik dapat dilihat dari segi kuantitas, yaitu berapa banyak jumlah hasil kerja yang telah dihasilkan dan kualitas, yaitu tingkat baik atau buruknya hasil kerja yang dihasilkan dalam kurun waktu tertentu.

\section{METODE PENELITIAN \\ Lokasi dan Objek Penelitian}

Penelitian ini dilaksanakan di Biro Rektorat Universitas Jabal Ghafur.Objek penelitian adalah Pengaruh Implementasi Sistem Pengembangan Sumber Daya Manusia yang terdiri dari Pendidikan dan Pelatihan terhadap kinerja karyawan Biro Rektorat Universitas Jabal Ghafur.

\section{Populasi dan Sampel Penelitian Populasi}

Populasi adalah keseluruhan subjek penelitian.Populasi dalam penelitian ini adalah semua karyawan Biro Rektorat Universitas Jabal Ghafur sebanyak 55 Orang Karyawan.

\section{Sampel}

Pengambilan sampel dalam penelitian ini adalah menggunakan total sample yaitu seluruh populasi di jadikan sampel.Sampel penelitian ini sebanyak 55 Orang.

\section{Teknik Pengumpulan Data}

Wawancara (interview), yang dilakukan kepada pihak yang berhak dan berwenang memberikan informasi dan data di Biro Rektorat Universitas Jabal Ghafur.

Daftar Pertanyaan (kuesioner), yang diberikan kepada Karyawan Biro Rektorat Universitas Jabal Ghafur sebagai responden.

Studi Dokumentasi, dengan mengumpulkan, mempelajari dan menganalisis data-data, dokumen berupa laporan dan peraturan-peraturan yang berkaitan dengan pelaksanaan penelitian.

\section{Skala Pengukuran Variabel}

Dalam penelitian ini penulis menggunakan skala Likert yaitu digunakan untuk mengukur sikap, pendapat dan persepsi seseorang atau kelompok orang tentang fenomena sosial, yang selanjutnya disebut sebagai variabel penelitian. Dalam melakukan penelitian terhadap variabelvariabel yang akan diuji pada setiap jawaban akan diberikan skor Sugiyono (2009:135). Untuk keperluan analisis kuantitatif penelitian memberikan lima alternative jawaban kepada responden dengan menggunakan skal 1 sampai 5.

Tabel 3.1

Skor Penilaian

\begin{tabular}{|l|l|c|}
\hline No & \multicolumn{1}{|c|}{ Alternatif Jawaban } & Skore \\
\hline 1 & Sangat Setuju (SS) & 5 \\
2 & Setuju (S) & 4 \\
3 & Kurang Setuju (KS) & 3 \\
4 & Tidak Setuju (TS) & 2 \\
5 & Sangat Tidak Setuju (STS) & 1 \\
\hline
\end{tabular}

Teknik Analisa Data

\section{Analisis Deskriptif Statistik}

Statistika deskriptif berkenaan degan bagaimana data dapat digambarkan atau disimpulkan baik secara numerik (misalnya menghitung rata-rata dan deviasi standar) atau

Jurnal Sains Riset | Volume VIII Nomor I 
secara grafis (dalam bentuk tabel atau grafik) untuk mendapatkan gambaran sekilas mengenai data tersebut sehingga lebih mudah dibaca dan bermakna.

\section{Analisis Statistik Inferensial Pengujian Asumsi Klasik}

Formulasi regresi berganda dipergunakan karena secara teoritis variabel dependen yang diteliti dianggap mempunyai kecenderungan hubungan linier dengan masing-masing variabel independennya. Regresi linier berganda mencocokkan model prediksi ke dalam sebuah model yang telah dimasukkan ke dalam serangkaian data, masalah ini disebut dengan pengujian asumsi klasik yangdi dalamnya termasuk pengujian normalitas, multikolinieritas, heterokedastisitas (Ghozali, 2009 :19).

\section{HASIL}

\section{Pengaruh \\ Implementasi \\ Pengembangan Sumber Daya Manusia Terhadap Kinerja Karyawan \\ Untuk mengetahuipengaruh Pendidikan dan Pelatihan terhadap kinerja karyawan pada biro Rektorat Universitas Jabal Ghafur, maka dilakukan analisis data melalui regresi linear berganda.Dimana hasilnya dapat dilihat pada Tabel4.9 berikut: \\ Tabel 4.9 \\ Pengaruh Masing-masing Variabel Independen \\ Terhadap Variabel Dependen}

Sistem

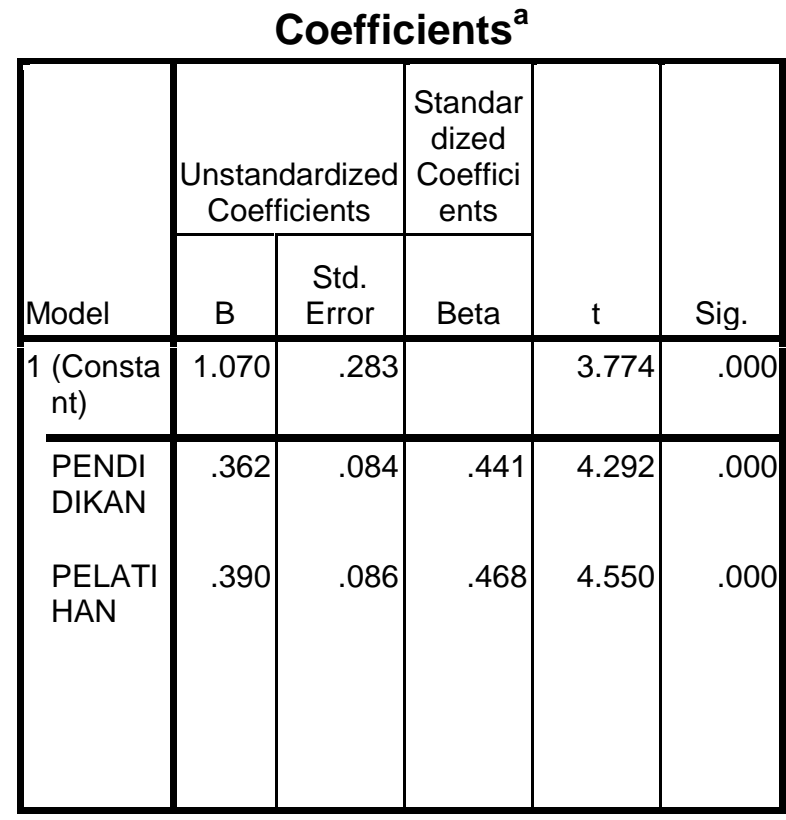

Coefficients $^{a}$

\begin{tabular}{|l|r|r|r|r|r|}
\hline & \multicolumn{1}{|c|}{$\begin{array}{r}\text { Unstandardized } \\
\text { Coefficients }\end{array}$} & $\begin{array}{r}\text { Standar } \\
\text { dized } \\
\text { Coeffici } \\
\text { ents }\end{array}$ & & \\
\cline { 2 - 6 } Model & \multicolumn{1}{|c|}{$\mathrm{B}$} & \multicolumn{1}{c|}{$\begin{array}{c}\text { Std. } \\
\text { Error }\end{array}$} & Beta & $\mathrm{t}$ & \multicolumn{1}{c|}{ Sig. } \\
\hline $\begin{array}{l}1 \text { (Consta } \\
\text { nt) }\end{array}$ & 1.070 & .283 & & 3.774 & .000 \\
\hline $\begin{array}{l}\text { PENDI } \\
\text { DIKAN }\end{array}$ & .362 & .084 & .441 & 4.292 & .000 \\
$\begin{array}{l}\text { PELATI } \\
\text { HAN }\end{array}$ & .390 & .086 & .468 & 4.550 & .000 \\
\hline
\end{tabular}

a. Dependent Variable: KINERJA

Sumber: Hasil Pengolahan SPSS (2016)

Berdasarkan hasil pengolahan regresi berganda yang ditujukkan dalam Tabel 4.9 maka diperoleh hasil regresi berganda sebagai berikut:

$\mathrm{Y}=\mathrm{a}+\mathrm{b} \_1 \mathrm{X} \_1+\mathrm{b} \_2 \mathrm{X} \_2$

$\mathrm{Y}=1,070+0,362 \mathrm{X} 1+0,390 \mathrm{X} 2$

Berdasarkan persamaan tersebut dapat diuraikan sebagai berikut:

1. Konstanta (a) $=1,070$ ini memiliki arti bahwa variabel pendidikan (X1), pelatihan (X2) diobjek penelitian sama dengan nol, maka sebesarnya nilai 1,070 .

2. Koefisien $\mathrm{X} 1(\mathrm{~b} 1)=0,326$. Ini menunjukkan bahwa variabel Pendidikan berpengaruh secara positif terhadap kinerja karyawan pada biro Rektorat Universitas Jabal Ghafur, atau dengan kata lain, jika variabel Pendidikan ditingkatkan, maka kinerja karyawan akan bertambah sebesar 0,328.

3. Koefisien X2 (b2) $=0,390$. Ini menunjukkan bahwa variabel Pelatihan berpengaruh secara positif terhadap kinerja karyawan pada biro Rektorat Universitas Jabal Ghafur, atau dengan kata lain, jika variabel Pelatihan ditingkatkan, maka kinerja karyawan akan bertambah sebesar 0,390 .

\section{Hasil Pengujian Hipotesis Uji F}

Uji $F$ dilakukan untuk melihat pengaruh variabel independen terhadap variabel dependen secara bersama-sama (secara simultan).Model 
hipotesis yang digunakan dalam Uji $\mathrm{F}$ ini adalah sebagai berikut:

1. $\mathrm{H} 0: \mathrm{b} 1, \mathrm{~b} 2,=0$ artinya secara serentak tidak terdapat pengaruh yang positif dan signifikan dari variabel bebas, Pendidikan dan Pelatihan terhadap variabel terikat (kinerja karyawan).

2. $\mathrm{Ha}: \mathrm{b} 1, \mathrm{~b} 2=0$ artinya secara serentak terdapat pengaruh yang positif dan signifikan dari variabel bebas, Pendidikan dan Pelatihan terhadap variabel terikat (kinerja karyawan). Peneliti dalam menentukan nilai $\mathrm{F}$, maka diperlukan adanya derajat bebas pembilang dan derajat bebas penyebut, dengan rumus sebagai berikut :

df (pembilang $)=k-1$

$\mathrm{df}($ penyebut $)=\mathrm{n}-\mathrm{k}$

keterangan :

$\mathrm{n}=$ jumlah sampel penelitian

$\mathrm{k}=$ jumlah variabel bebas dan terikat

Padapenelitian ini diketahui jumlah sampel (n) adalah 55 dan jumlah keseluruhan variabel (k) adalah 3, sehingga diperoleh:

1. $\mathrm{df}$ (pembilang) $=\mathrm{k}-1 \quad \mathrm{df}$ (pembilang) $=3-1=2$

2. $\mathrm{df}($ penyebut $)=\mathrm{n}-\mathrm{k} \quad \mathrm{df}($ penyebut $)=$ $55-2=53$

Nilai Fhitung akan diperoleh dengan bantuan software SPSS 21.0 for Windows, kemudian akan dibandingkan dengan nilai Ftabel pada tingkat $\alpha=5 \%(2: 53)=3,17$ (berdasarkan Ftabel), dengan kriteria sebagai berikut:

1. H0 diterima jika Fhitung $<$ Ftabel pada $\alpha=$ $5 \%$

2. H0 ditolak jika Fhitung $>$ Ftabel pada $\alpha=$ $5 \%$

Tabel 4.10

Hasil Analisis Uji F

ANOVA $^{\text {b }}$

\begin{tabular}{|c|c|c|c|c|c|}
\hline Model & $\begin{array}{l}\text { Sum of } \\
\text { Squares }\end{array}$ & df & $\begin{array}{l}\text { Mean } \\
\text { Square }\end{array}$ & $\mathrm{F}$ & Sig. \\
\hline $\begin{array}{l}1 \text { Reg } \\
\text { ress } \\
\text { ion }\end{array}$ & 6.793 & 2 & 3.397 & $\begin{array}{r}55.41 \\
2\end{array}$ & $.000^{\mathrm{a}}$ \\
\hline $\begin{array}{l}\text { Resi } \\
\text { dual }\end{array}$ & 3.188 & 52 & .061 & & \\
\hline $\begin{array}{l}\text { Tota } \\
\text { I }\end{array}$ & 9.981 & 54 & & & \\
\hline
\end{tabular}

a. Predictors: (Constant), PELATIHAN, PENDIDIKAN

b. Dependent Variable: KINERJA
Sumber: Hasil Pengolahan SPSS (2016)

Berdasarkan tabel 4.10 dapat dilihat Fhitung adalah 55,412 dengan tingkat signifikan 0,000 . Oleh karena itu, pada kedua perhitungan yaitu Fhitung> Ftabel $(55,421>3,17)$ dan tingkat signifikansinya $0,000<0,05$. Hal ini menunjukkan bahwa $\mathrm{HO}$ ditolak dan Ha diterima, yang artinya variabel bebas, yang terdiri dari Pendidikan dan Pelatihan secara bersama-sama berpengaruh positif dan signifikan terhadap variabel terikat (kinerja karyawan biro Rektorat Universitas Jabal Ghafur).

\section{Uji t}

Uji tdilakukan untuk melihat signifikan dari pengaruh variabel independen secara individu terhadap variabel dependen (secara parsial). Model hipotesis yang akan dilakukan adalah sebagai berikut :

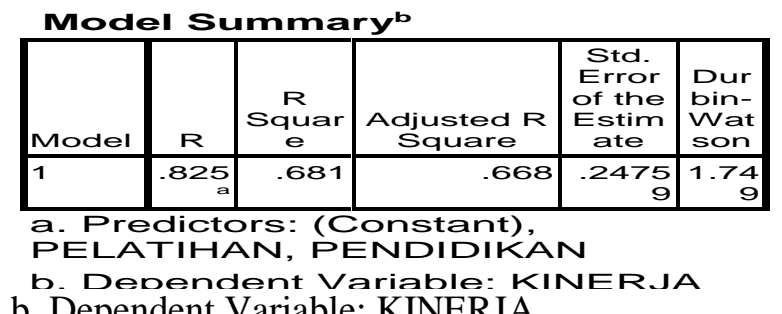

b. Dependent Variable: KINERJA

1. $\mathrm{H} 0: \mathrm{b} 1=\mathrm{b} 2=0$, artinya secara parsial tidak terdapat pengaruh yang positif dan signifikan dari variabel independen terhadap variabel dependen.

2. H0 : b1 $\nexists 2 \neq 0$, artinya secara parsial terdapat pengaruh yang positif dan signifikan dari variabel independen terhadap variabel dependen.

Kriteria pengambilan keputusan adalah:

a. H0 diterima jika thitung $<$ ttabel pada $\alpha$ $=5 \%$

b. H0 ditolak jika thitung > ttabel $\alpha=5 \%$

Tingkat kesalahan $(\alpha)=5 \%$ dan derajat kebebasan $(\mathrm{df})=(\mathrm{n}-\mathrm{k})$

$\mathrm{n}=$ jumlah sampel, $\mathrm{n}=55$

$\mathrm{k}=$ jumlah variabel yang digunakan, $\mathrm{k}=3$

Maka: derajat bebas (df) $=\mathrm{n}-\mathrm{k}=55-3=52$

Uji t yang digunakan adalah uji dua arah, maka ttabel yang digunakan adalah t0,05(52) =2,006.

Tabel 4.11

Hasil Analisis Uji t 
Sumber: Hasil Pengolahan SPSS (2016)

bahwa:

Berdasarkan Tabel 4.11 menunjukkan

1. Variabel Pendidikan berpengaruh secara positif dan signifikan terhadap Kinerja Karyawan Biro Rektorat Universitas Jabal Ghafur. Hal ini terlihat dari nilai signifikan $(0,000)$ lebih kecil dari 0,05 dan nilai thitung 4,292 >ttabel2,006.

2. Variabel Pelatihan berpengaruh secara positif dan signifikan terhadap Kinerja Karyawan Biro Rektorat Universitas Jabal Ghafur. Hal ini terlihat dari nilai signifikan $(0,000)$ lebih kecil dari 0,05 dan nilai thitung4,550> ttabel 2,006.

\section{Identifikasi Determinan (R2)}

Determinan digunakan untuk melihat seberapa besar pengaruh variabel independent terhadap variabel dependent. Jika determinan (R2) semakin besar atau mendekati satu, maka pengaruh variabel independent $(\mathrm{X} 1, \mathrm{X} 2)$ terhadap variabel terikat (Y) semakin kuat. Jika determinan (R2) semakin kecil atau mendekati nol maka pengaruh variabel independent (X1, X2) terhadap variabel dependent (Y) semakin lemah.

Tabel 4.12 menunjukkan bahwa nilai $\mathrm{R}=$ 0,825 berarti hubungan antara variabel Pendidikan dan Pelatihan terhadap variabel dependent Kinerja karyawan sebesar 82,5\%, artinya hubungannya sangat erat. Angka $R$ Square sebesar 0,681 berarti $68,1 \%$ faktor-faktor Kinerja Karyawan dapat dijelaskan oleh Pendidikan dan Pelatihan sedangkan sisanya $31,9 \%$ dapat dijelaskan oleh faktor-faktor lain yang tidak diteliti dalam penelitian ini. Angka Adjusted R2 atau determinan sebesar 0,681 berarti $68.1 \%$ faktor-faktor kinerja karyawan dapat dijelaskan oleh Pendidikan (X1), Pelatihan (X2), sedangkan sisanya 31,9\% dapat dijelaskan oleh faktor-faktor lain yang tidak diteliti dalam penelitian ini.

\section{DAFTAR PUSTAKA}

As'ad Moh.2006. Kepemimpunan Efektif dalam Perusahaan.Yogyakarta: Liberty.

Bernardin, H. John dan Joyce E.A. Russell. 2006. Human Resource Management. Singapore : McGraw Hill Inc.

Erlina.2008. Metodologi Penelitian Bisnis: Untuk Akuntansi dan Manajemen. Medan: USU Press.

\section{Coefficients $^{\mathrm{a}}$}

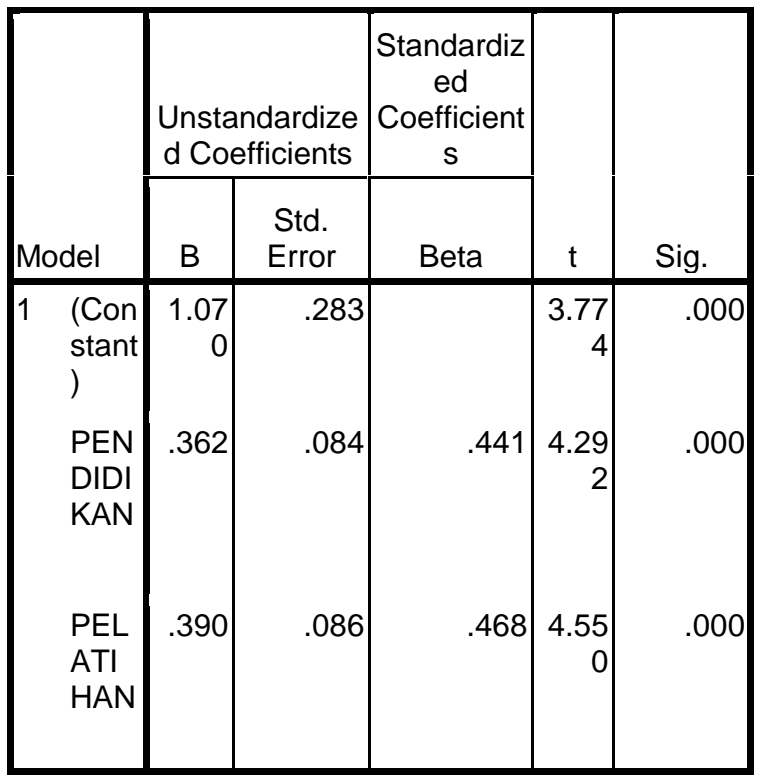

a. Dependent Variable: KINERJA

Gibson, J. L., Ivancevich, J. M., dan J. H. Donnelly. 2006. Organizations: Behavior, Structure, Processes. Jakarta: Binarupa Aksara.

Gomes, Faustino Cardoso.2008. Manajemen Sumber Daya Manusia. Cetakan keempat.Yogyakarta: AndiOffset.

Handoko, T. Hani.2008. Manajemen Personalia Sumber Daya Manusia, Edisi.Kedua. Yogyakarta:BPFE.

Hasibuan, Malayu. 2013. Manajemen Sumber Daya Manusia. Jakarta: BumiAksara.

Jogiyanto, H.M. 2005.Analisa dan Desain Sistem Informasi: Pendekatan. Terstruktur Teori dan Praktik Aplikasi Bisnis. Yogyakarta: ANDI

Kirkpatrick, D.L. 2006.Evaluating Training Programs, The four Levels (2nded.). Berrett-Koehler Publisher, Inc., San Francisco.

Komaruddin, Sastradipoera. 2010. Manajemen Sumber Daya Manusia: suatupendekatan fungsi operatif. Bandung: Kappa-Sigma.

Kusumanegara, Solahuddin. 2010. Model dan Aktor Dalam Proses Kebijakan Publik. Yogyakarta: Gava Media

LAN dan DEPDAGRI. 2007. Modul 2 Pengembangan Sumber Daya ManusiaPegawai Negeri Sipil, Diklat Teknis Manajemen Sumber Daya Manusia. Jakarta. 
Mangkunegara, Anwar Prabu. 2009. Perencanaan dan Pengembangan Sumber Daya Manusia. Bandung: Reflika Diatama

Mardi. 2011. Sistem Informasi Akuntansi. Bogor: Ghalia Indonesia.

Mathis, Robert, L. dan John H Jackson. 2008. Manajemen Sumber Daya Manusia Buku 1. (Jimmy Sadell \& Bayu Prawira Hie, Penerjemah)Jakarta: Salemba Empat.

Nawawi, H. Hadari. 2005. Instrumen Penelitian Bidang Sosial.Yogyakarta: Gadjah MadaUniversity Press.

Notoadmodjo, Soekidjo. 2009. Pengembangan sumber Daya Manusia. Jakarta:Rineka Cipta.

Probosemi, K. 2011. Analisis Kebutuhan Pelatihan Karyawan Bidang Pelayanan Pasa PT TASPEN (Persero) Kantor Cabang Bogor. SkripsiSarjana pada Fakultas Ekonomi dan Manajemen Institut Pertanian Bogor:tidak diterbitkan.

Rivai, Veithzal, 2005. Manajemen Sumber Daya Manusia untuk Perusahaan, dari Teori ke Praktik.Jakarta: PT. Raja Grafindo Persada

Robbins, Stephen P. 2006. Perilaku organisasi: konsep, kontroversi, aplikasi(Hadyana Pujaatmaka, Penerjemah). Jakarta: Prenhallindo.

Schuler, Randal S. dan Jackson, Susan E, 2006, Manajemen Sumber Daya Manusia Menghadapi Abad ke 21, Jilid 2, Edisi Keenam. Jakarta: Erlangga

Siagian, Sondang P. 2009. Manajemen Sumber Daya Manusia. Jakarta: PT. Bumi Aksara.

Simamora, Henry. 2006. Manajemen Sumber Daya Manusia, Edisi 2. Yogyakarta: STIE YKPN

Sinaga. 2010. Pengaruh Pendidikan dan Pelatihan Terhadap Kinerja Pegawai Negeri Sipilpada Kantor Regional IV Badan Kepegawaian Negara (BKN) Medan.Skripsi Sarjana pada Fakultas Sosial dan Politik Universitas SumateraUtara: tidak diterbitkan.

Sutrisno, Edy, 2010.Budaya Organisasi. Jakarta:Kencana Prenada Media Group.

Suprihanto J. 2006. Penilaian Kinerja dan Pengembangan Karyawan. Yogyakarta: BPFE.
Sofyandi, Herman. 2008. Manajemen Sumber Daya Manusia. Yogyakarta: Graha Ilmu.

Tachjan, H. 2006. Implementasi Kebijakan Publik. Bandung: Truen RTH.

Wibisono, Dermawan. 2006. Manajemen Kinerja. Jakarta: Erlangga.

Winkel \& Sri Hastuti.2004. Bimbingan dan Konseling di Institusi Pendidikan. Yogyakarta: Media Abadi. 